\title{
LENGTH AND SYLLABLE WEIGHT IN IBIBIO*
}

\author{
Eno-Abasi E. Urua \\ University of Uyo, \\ Uyo, Nigeria
}

This paper presents a study of segment length and its relationship to the syllable in Ibibio, a Lower Cross language spoken in Nigeria. Syllable structure pro-cesses such as consonant lengthening, lenition, vowel lengthening and trunca-tion all occur to satisfy syllable weight requirements.

\subsection{Introduction}

The issue of length and its linguistic representation has been of interest to linguists for many years. One reason for this is that long segments sometimes function as a sequence of short segments and at other times as a single unit. Research on Hausa plurals [Leben 1980], Berber [Guerssel 1977], Hebrew [Barkai 1974; McCarthy 1981] and Greek [Schein \& Steriade 1986] provide some of the evidence for this position. Given a non-linear approach, length can be viewed as an autonomous property on an independent tier of the phonological representation, separate yet related to the segmental tier (cf. Smith \& Van der Hulst [1982]; Hyman [1982]). In the present study, I seek to extend the results of this previous work to Ibibio, a Lower Cross language spoken in Akwa Ibom State in the southeastern part of Nigeria.

I investigate here length phenomena in both consonants and vowels in Ibibio. Two different consonant processes-lengthening and lenition-occur in what appears to be the same intervocalic environment. Vowels, too, may be affected, either lengthened or truncated. The question this raises is why this should be the case. Although it appears superficially that the environments for consonantal lengthening and lenition are the same, on one hand, and the environments for vowel lengthening and truncation identical, on the other hand, there is a crucial distinction

* I am grateful to Bruce Connell for useful comments and discussions as well as for literally rewriting the introductory part of this paper. I would also like to thank John Harris for insightful comments, the anonymous reviewers and the SAL editor for comments on earlier drafts of this paper. 
in terms of syllable weight. Hence, the position adopted here is that of moraic phonology, which assumes a basic weight distinction between different syllable types. Adopting such an approach, I believe, clarifies and simplifies the analysis of length phenomena in Ibibio.

The paper is organised along the following lines. In section 2 a phonological sketch of Ibibio is presented. Section 3 provides data and a descriptive account of length in Ibibio, followed by an account of previous analyses of length in section 4 . Length and syllable weight constitute the focus of section 5. Section 6 presents concluding remarks. Examples in the paper are given in phonetic representation.

\subsection{Ibibio phonological sketch}

Ibibio manifests dialect variation depending on the clan groupings within Ibibio land. The varieties used in this study are those spoken in the Uyo (the state capital), Uruan, and Etinan areas, broadly covering the Uruan and Iman dialects. The data collected in these areas cut across sex and age. Being a native speaker of the Ibibio language myself, I can confirm that distinctive vowel length, exemplified by the examples in (1), is quite widespread across the Lower Cross group to which Ibibio belongs

$\begin{array}{lll}\text { (1) Ibibio } & \text { Annang } & \text { Gloss } \\ \text { nám } & \text { nám } & \text { 'do' } \\ \text { náam } & \text { náam } & \text { 'intoxicate' } \\ \text { djk } & \text { djok } & \text { 'dig (a) hole' } \\ \text { dóśk } & \text { dók } & \text { 'climb' }\end{array}$

Various analyses of the Ibibio phoneme system are found in the literature. For the purpose of this paper, we assume a system consisting of thirteen consonant phonemes and seven vowel phonemes ${ }^{1}$ [Urua 1990], plus a length feature for six of these vowels, as shown in (2).

$$
\begin{aligned}
& \text { /i, e, a, } \iota, \text { o, o, u/ } \\
& \text { /ii, ee, aa, oว, oo, uu/ }
\end{aligned}
$$

2.1 Ibibio vowel phonemes. There is some debate in the literature concerning the number of vowel phonemes found in Ibibio [Kaufman 1968, 1985, Essien 1983, 1990, Utip 1991, Urua 1990]. This may, to some extent, be due to dialect variation, but to some extent it is also due to problems in analysis. In this work, we assume a seven-vowel inventory, as listed in (3).

$$
\text { li, e, a, } \Lambda, \mathrm{o}, \mathrm{o}, \mathrm{u} /
$$

1 The vowel phonemes have posed major difficulties for analysts, and this has resulted in a range of different proposals. Six vowel phonemes are proposed by Kaufman [1968]; seven by Boys [1978] and Urua [1990]; eight by Connell [1991]; nine by Utip [1991] and ten by Essien [1983, 1990], largely as a result of dialect variation. 
Apart from $/ \Lambda /$, which is restricted in distribution to $C_{-} C$ position, the other six vowels are realised as such in open syllables. In closed syllables, there is a degree of shortening and centralisation, especially for the higher vowels, such that $/ \mathrm{i}, \mathrm{o}, \mathrm{u} /$ are realised as $[\dot{i}, \partial, \mathrm{t}]$, respectively. The symbol [i] represents a lowered and centralised high front vowel.

These six vowels may all occur in prefixes, typically with their open syllable realisations, though there appears to be some dialect variation with respect to realisation, which may be due to variation in the harmony system; it remains a question that requires further exploration. There are restrictions as to which vowels may occur in suffixes; typically /i, u/ do not occur, and the phonetic realisation of those vowels that do is determined by harmony considerations which vary across dialects. The facts of vowel harmony across Ibibio dialects are of substantial interest but do not bear on the issues discussed in this paper.

Ibibio exhibits phonemic vowel length, a fact on which all writers agree, though there is some debate as to whether all vowels may be lengthened. The high vowels /i/ and $/ \mathrm{u} /$, in particular, are problematic in this regard, where a length contrast seems restricted to northern dialects.

Vowel length may also be derived, indicating the frequentative or pluractional nature of verbs; it also occurs ideophonically for pragmatic purposes. Constraints on the distribution of Ibibio vowels are summarised in (4).

(4) Vowel distribution

$\begin{array}{llll}\text { Prefix } & \text { C_C } & \text { Final } & \text { Suffix } \\ \text { i } & \text { ii, i } & \text { i } & \\ \text { e } & \text { ee, e } & \text { e } & \text { e } \\ \text { a } & \text { aa, a } & \text { a } & \text { a } \\ \text { o } & \text { os, o } & \text { o } & \text { o } \\ \text { o } & \text { oo, o } & \text { o } & \text { o } \\ \text { u } & \text { uu, u } & \text { u, u } & \\ & \Lambda, \partial & & \end{array}$

2.2 Ibibio consonant phonemes. Ibibio has thirteen consonants in its phonemic inventory [Urua 1990]. The consonant system is particularly interesting for the restrictions that exist on the distribution and phonetic realisation of these consonants, and for the exceptions to what appears to be the basic system. Exceptions apart, it can be said that all consonants may occur stem initially, and that in this position they are typically realised with a "strong" articulation. In final position (i.e., prepausally), only stops and nasals may occur, with the stops normally being voiceless. In intervocalic, non-stem initial position, distribution is similarly restricted, though phonetic realisations are typically weak, i. e., lenition occurs. The facts of the basic system are summarised in Table 1. Symbols have IPA values with the exception of [R], which represents a uvular approximant or tap.

Exceptions to this basic system are as follows. First, the approximant $/ \mathrm{j} /$ could also be said to occur in final and medial positions. The essence of the debate here is 
Table 1: The basic Ibibio consonant system, with positional variants.

$\begin{array}{ccccc}\text { Consonant } & \text { \#C } & \text { C\# } & - \text { VCV- } & \text {-VCCV- } \\ \text { b } & \text { b } & \text { p } & \text { b, } \beta & \text { pp } \\ \text { t } & \mathrm{t} & \mathrm{t} & \mathrm{r} & \mathrm{tt} \\ \mathrm{d} & \mathrm{d} & \mathrm{d} & \mathrm{r} & \\ \mathrm{k} & \mathrm{k} & \mathrm{k} & \mathrm{R} & \mathrm{kk} \\ \mathrm{kp} & \mathrm{kp} & - & \mathrm{kp} & \\ \mathrm{m} & \mathrm{m} & \mathrm{m} & \mathrm{m} & \mathrm{mm} \\ \mathrm{n} & \mathrm{n} & \mathrm{n} & \mathrm{n} & \mathrm{nn} \\ \mathrm{n} & \mathrm{n} & - & - & \\ \mathrm{n} & \mathrm{jw} & \mathrm{\eta} & \mathrm{\eta} & \mathrm{n} \\ \mathrm{f} & \mathrm{f} & - & - & \\ \mathrm{s} & \mathrm{s} & - & \mathrm{s} & \\ \mathrm{j} & \mathrm{j} & \mathrm{j} & - & \mathrm{jj} \\ \mathrm{w} & \mathrm{w} & - & \mathrm{w} & \end{array}$

whether post-vocalic [j] is part of the nucleus, i.e., forming a diphthong, or is a coda consonant. The latter analysis is assumed in this paper, following Urua [1990], and Akinlabi and Urua [1993] (see also 3.2.2, below).

The more interesting set of exceptions to the basic system is the occurrence, in medial position, of what may be termed "long" or geminate consonants. Clearly, $/ \mathrm{mm} /, / \mathrm{nn} /$, and $/ \mathrm{n} \mathrm{\eta} /$ do occur contrastively in this environment, as the examples in (5) show.
(5) a. démé 'ignore'
démmé 'wake up'
yòmó 'be noisy'
yòmmó 'boo at'

b. dónó 'be smooth'

dónnó 'slip (on a slippery surface)'

mónó 'be smooth'

mónnó 'shine (a) torch'

c. Đwàná 'be transparent'

jwàngá 'pour (e.g., into a container)'

It may also be argued that $/ \mathrm{p}, \mathrm{t}, \mathrm{k} /$ occur as long consonants in this same environment. This claim is somewhat more contentious, in that phonetically no "short" voiceless stops occur in this position with which the ostensibly long ones contrast. Contrast can be said to occur, though, with the lenited realisations of other consonants in medial position, as seen in (6). This phenomenon is proble- 
matic for the neatness of the basic system in that it can no longer be claimed that all consonants in the inventory contrast in initial position.
(6) a. díppé $d^{\prime} \beta$ $\beta$ é
'lift up'
'hide oneself'
b. sítté
'bore (e.g., a hole')
síré
'be bushy'
c. díkké
dłrRé
'frighten'
'step on'

A second critical factor affecting the assumption of long voiceless stops is that some, though by no means all, occurrences of medial /pp, $\mathrm{tt}, \mathrm{kk} /$ are a result of morphological processes, typically the addition of a -CV suffix to a CVC stem, where the initial $\mathrm{C}$ of the suffix is assimilated to the stem-final $\mathrm{C}$. The stop consonants are an important case in point. It is often a thorny issue to decide how to analyze the relationship among the labial stops [p, b, kp] in the language. Sometimes [p] and [kp] have been assigned to the same phoneme; at other times [p] and [b] have been assigned to one phoneme, and so forth. It has even been suggested that $[\mathrm{p}]$ might belong with /f/. Since this paper does not strictly concern the phonological analysis of Ibibio phonological units, I have simply presented the constraints that affect these consonants and present the distribution as in Table 1 above.

2.3 Ibibio syllable structure. Although there are segment and syllable structure constraints on what may occur where, Ibibio syllable structure is uncomplicated, basically $\mathrm{CV}(\mathrm{V})(\mathrm{C})$. Verb stems may have an initial $\mathrm{V}$ or $\mathrm{N}$ prefix, which may be followed by an open syllable (either light or heavy) or by a closed syllable having either a short or long vowel.

2.4 Ibibio tone. There are two contrastive level tones, high and low, plus a downstep feature. Other tones are the contour rising (low-high) and falling (high-low) tones, which are combinations of high and low tones. The following marking conventions are used: ['] High tone; [ ] Low tone, [ ], Low-high rising; [^] Highlow falling, and Downstepped high tone [!]. All tone-bearing segments are marked for tone.

\subsection{A descriptive account of length in Ibibio}

3.1 Long vowels. Verb roots may differ in whether they exhibit short or long vowels, a few examples of CV and CVV types being provided in (7). Even though long vowels occur in open syllables, as in the examples in (7b), such examples are rare; minimal pairs exhibiting a contrast between short and long vowels in this environment do not exist. 
(7) a. CV roots

tá 'chew'
sé 'look'
nò 'give'
mà 'complete (a task)'

b. CVV roots

nàá 'lie down'

kàá 'go'

Of the seven vowels identified in this study, six (/i, e, a, o, o, u/) may occur as long vowels in contrast with short ones, generally in closed syllables. Minimal pairs exhibiting a phonological length contrast are presented in (8). Observe in (9) that, although there are long high vowels /ii/ and /uu/ in C_C position, there are no items with the corresponding short high vowels, /i/ and /u/. This is essentially because there is a constraint that bars high vowels from occurring in certain positions, namely C_C and as suffix vowels, as indicated above in (4).

(8) Vowel length contrasts déép
'scratch'
b. nám 'perform/do'
náám 'intoxicate'
a. dép 'buy'
mèk
mè̀
'choose'
'bend'
c. bók 'cook'
bóśk 'nurture'
d. ókóp 'navel'
ókóóp 'calabash’
(9) a. siít
b. túúk
'block (an) opening'
'touch'

Long vowels may be underlying, as above, or occur through derivation. In (10), vowel length is a consequence of verbal derivational morphology. The frequentative, 2 for example, may simply lengthen the vowel of the verb root, as in (10a), or append a suffix with concomitant lengthening of the verb stem vowel, as in (10b).

2 It must be pointed out that not all verbs in Ibibio are capable of indicating frequency through vowel lengthening. Other verbs achieve this through palatalisation, reduplication, or repetition. 
(10) a. Morphological vowel lengthening

Simple Root Frequentative

$\begin{array}{lll}\text { wèt } & \text { wèèt } & \text { 'write' } \\ \text { nám } & \text { náám } & \text { 'sell' } \\ \text { wòt } & \text { wò̀t } & \text { 'kill' }\end{array}$

b. Vowel lengthening and suffixation

Simple Root Frequentative

$\begin{array}{lll}\text { fèré } & \text { fèè-mé } & \text { 'run' } \\ \text { dép } & \text { déé-mé } & \text { 'buy' } \\ \text { kíppó } & \text { kúú-mó } & \text { 'uncover (e.g., bottle)' }\end{array}$

Although simple lengthening of the root vowel marks frequency in some verbs (10a), much more than this is involved in the cases in (10b). In addition to root vowel lengthening, a -CV suffix also appears. The -C- of this suffix is underlyingly [Nasal], while vowel harmony constraints determine the quality of the $-\mathrm{V}$ of the suffix. As I intend to show in section 5, this is not simply a question of consonant nasalisation, as suggested by Essien [1979], but more particularly a process of compensatory lengthening. The suffix -C- is specified for the feature [Nasal] which is homorganic to the final consonant in the CVC verb stem. The final $\mathrm{C}$ of the verb stem is lost, with subsequent lengthening of the stem vowel to fill the slot of the lost final C.

Although long vowels are attested in noun forms, they do not usually contrast with short vowels in the same environment. It is a difficult task to find even near minimal pairs such as ídáárá 'joy' and údárà 'type of cherry (with sticky flesh)'. It is instructive to note that these nouns are frequently derived via affixation from verb roots having long vowels.
(11) Nouns
Verb Root
ítòòró 'praise'
tòòró 'praise'
ídáárá 'joy’
dáárá 'rejoice'
íbう̀̀̀rò 'response'
bj̀̀̀r̀̀ 'respond'
ùbè̀t 'room'
bèèt
'shut (e. g., doors, windows) (Freq.)
ùbêt
'your husband' (from bèt 'to support')

Although length may be a feature of both nouns and verbs, the data in this paper are drawn largely from the verbal class because this is the class where length is used for phonological and morphological contrast.

3.2 Long consonants. Ibibio attests long consonants whose distribution is restricted to intervocalic position. Hence, one does not find long consonants in wordor stem-initial or final position. In this paper, I make a distinction between long consonants that have a contrastive function and mere phonetically long consonants 
with no contrastive function. Those long consonants that exhibit a distinctive contrastive function are the nasal stops. Voiceless oral stops and the palatal glide, on the other hand, may occur phonetically as long consonants, but they have no contrastive function. Data in the following sections illustrate each kind of long consonants in Ibibio.

3.2.1 Inherent consonant length. Like vowel length, consonant length may be exploited phonologically to make a lexical contrast, as in (12), a contrast that is restricted to nasal consonants. Long voiceless and voiced oral consonants do not contrast in intervocalic position, as illustrated by the examples in (13). Although voiceless oral stops may occur as long consonants, I do not consider them to be phonologically significant since they do not contrast with a short counterpart.

(12) Contrastive nasal consonants
a. démé 'ignore'
démmé 'wake up'
yòmó 'be noisy'
b. dón's 'be smooth'
dónnó 'slip (on a slippery surface)'
yòmmó 'boo at'
mónó 'be smooth'
mónnó 'shine (a) torch'

(13) Phonetically long voiceless consonants

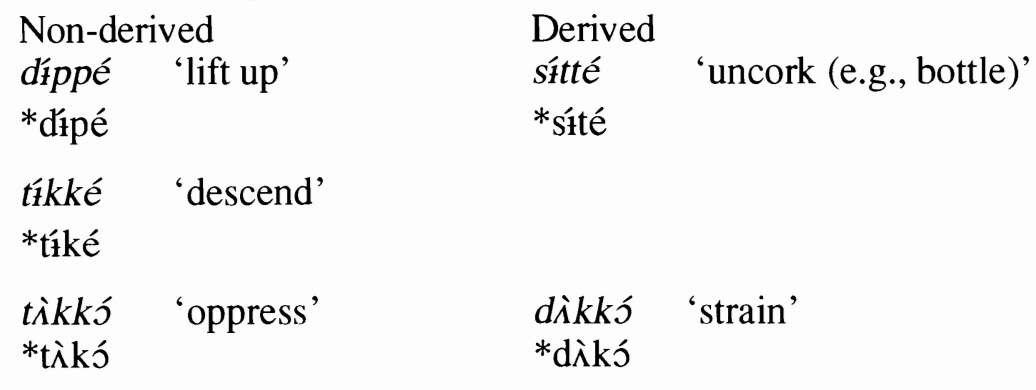

3.2.2 Derived consonant length. Consonant length may also result from morphological affixation, as in (14)-(16) which illustrate reversive and negative suffixes. In (14) appear derived geminate nasals; in (15) and (16) appear derived geminate voiceless stops, reversive and negative, respectively. Essien [1979, 1990] has claimed that both voiced and voiceless oral stops can occur as geminate/long consonants in Ibibio, a claim which has been refuted in Urua [1990] and Connell [1991], and by the data provided here. In addition to nasals and voiceless stops, palatal glides (16d) may also occur as long consonants.

Single consonants in Ibibio undergo intervocalic weakening, long consonants do not. This is one crucial reason for considering these consonants long, since it is not possible for weakening to apply to either consonant of a geminate cluster, as evidenced by the affixation of the reversive suffix in (15). 
(14) Reversive (stem-final nasal)
a. tèm 'cook'
tèm-mé
'remove cooking from fire'
b. byòm
'carry on (the) head'
byòm-mó
'remove (object) from head'

(15) Reversive (stem-final voiceless consonant)

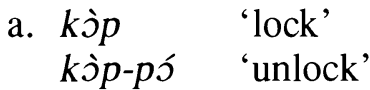
$\begin{array}{ll}\text { b. sítt } & \text { 'cork' } \\ \text { sitt-té } & \text { 'uncork' }\end{array}$

(16) Negative
a. dép
'buy'
1 dép-pé 's/he is not buying'
$\begin{array}{ll}\text { b. bàt } & \text { 'count' } \\ \text { I bàt-tá } & \text { 's/he is not counting' }\end{array}$
c. nék 'dance'
í nék-ké 's/he is not dancing'
$\begin{array}{ll}\text { d. bj̀y } & \text { 'receive (Freq)' } \\ \text { İ bj̀y-yó } & \text { 's/he is not receiving' }\end{array}$

The basic shapes of the suffixes are $-\mathrm{V}$ and $-\mathrm{CV}$. A single suffix shape and melody, as will be seen throughout this paper, may have multiple functions. Table 2 provides some of the different suffixes that attach to Ibibio verbs and the functions they perform. These suffixes are ordered, each one listed in Table 2 being ordered typically before the negative suffix, as shown in Table 3.

Table 2. Ibibio suffix type, function, and structure
$-\mathrm{V}$
Stative
[bùùk $+\mathrm{V}$
$\rightarrow b \grave{i} R-5$ 'be buried']
$-\mathrm{V}$
Reflexive
$\left[f \hat{k}^{\mathrm{k}}+\mathrm{V}\right.$
$\rightarrow$ fì $R$ - $\zeta$ 'cover oneself']
$-\mathrm{CV} / \mathrm{kV}$ Negative [tèm $+\mathrm{CV}$
$\rightarrow$...tèm-mé 'not cooking']
-CV Reversive [tèm + CV
$\rightarrow$ tèm-mé 'remove cooking from fire']
$-\mathrm{CV}$
Reciprocal
[è-dú-má + CV
$\rightarrow$ è-dú-kj̀m-mò 'love each other']
$-\mathrm{NV}$
Frequent.
$[$ dép $+\mathrm{NV}$
$\rightarrow$ déé-mé 'buy many things/times'] 
Table 3. Order of Ibibio verb suffixes
V-Stat-Neg bìró + Neg
$\rightarrow$...bìró-ké 'not being buried'
V-Refl-Neg fìró + Neg
$\rightarrow$... fìró-ké 'not covering oneself'
$\mathrm{V}-\mathrm{Rev}-\mathrm{Neg}$ tèmmé $+\mathrm{Neg}$
$\rightarrow$ tèmmé-ké 'not removing cooking from fire'
V-Rec-Neg è-dú-mà-kà + Neg $\rightarrow$ í-dú-kòmmò-ké 'they do not love each other'
V-Freq-Neg déé-mé + Neg $\rightarrow$...déémé-ké 'not buying many things/ times'

Reversive action is distinct from negative action in Ibibio. Whereas negative action negates the action of the verb, reversive action simply reverses or undoes the action. Moreover, verbs that show reversive action also take the negative suffix, just as regular positive verbs do. However, sometimes the structure and melody of the different suffixes are the same, as seen in (17b-c), where the negative suffix has the same structure and melody as the reversive suffix.

\section{(17)}
a. tèm
'cook'
b. tèm-mé
'remove cooking from fire (Rev)'
c. ń tèm-mé
'I am not cooking (Neg)'
d. ń tèm-mé-ké
'I am not removing cooking from fire (Rev Neg)'

Suffixation of the reversive suffix $-\mathrm{CV}$ to the verb stem tèm 'cook' creates a disyllabic stem. Disyllabic verb stems take the -ké negative suffix while monosyllabic verb stems take a $-\mathrm{CV}$ suffix, where the $\mathrm{C}$ is sometimes identical to the final consonant of the stem, as in (17b-c). This is reflected in (17d) where the negative suffix assumes the -ké shape. Moreover, the affixes are ordered with the negative suffix coming after the reversive suffix.

One problem in the analysis of long consonants in Ibibio has been how to handle glides. In previous studies, a vowel-glide sequence has been analysed as a diph-thong. For instance, the examples in $(18 \mathrm{~b}, \mathrm{~d}, \mathrm{f})$ were treated as a $\mathrm{CV}$ sequence in which the V was a diphthong. Similarly, cases such as that in (18e) were treated as CV-CV, kór-yó. There was no attempt to explain why the same sound was treated as part of a diphthong in the stem but as a glide in the suffix [Essien 1979; Umoh 1985; Urua 1987]. However, as has been argued in Urua [1990] and Akinlabi \& Urua [1993], such sequences are more properly regarded phonetically as $-\mathrm{VC}$, where the $\mathrm{C}$ is a palatal glide. This is because, morphophonemically, the sequence behaves like other CVC verbs rather than CV verbs, as shown in (19).

Observe that in (19), a -CV suffix is used to mark negation. This suffix has various allomorphs, e.g., $-\mathrm{RV}$ and $-\mathrm{CV}$ for verbs with the $\mathrm{CV}(\mathrm{C})$ structure, and -ké for $\mathrm{CV}(\mathrm{V}) \mathrm{C}(\mathrm{C}) \mathrm{V}$ verbs. However, the crucial examples are those in (19a-b). If, indeed, the VG sequences (19c) are diphthongs, then they would be expected to 
(18) a. bj̀ 'receive'

bj̀y 'receive (Freq)'

í bòy-yó 's/he is not receiving (Freq Neg)'

b. kóy 'fetch (liquid) with a cup'

í kóy-yó 's/he is not fetching (Freq Neg)'

c. dáy 'lick'

i dáy-yá 's/he is not licking (Freq Neg)'

(19) a. CV

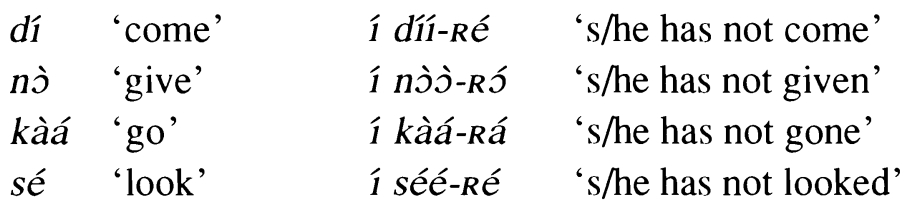

b. $\mathrm{CVC}\left(\mathrm{C}_{2}=\right.$ voiceless stop $)$

$\begin{array}{lll}\text { dép 'buy' } & \text { í dép-pé 's/he has not bought' } \\ \text { fòt 'peel' } & \text { í fòt-tó } & \text { 's/he has not peeled' }\end{array}$

c. $\mathrm{CVC}\left(\mathrm{C}_{2}=\right.$ glide $)$

bj̀y 'receive (Freq)' í bj̀y-yó 's/he has not received (Freq Neg)'

dáy 'lick' í dáy-yá 's/he has not licked'

\section{d. $\mathrm{CV}(\mathrm{V}) \mathrm{C}(\mathrm{C}) \mathrm{V}$}

$\begin{array}{ll}\text { màná 'be born' } & \text { i màná-ké 's/he has not been born' } \\ \text { bééné 'make (a) request' } 1 \text { bééné-ké 's/he has not made (a) request', } \\ \text { bèkké 'belch' } & \text { í békké-ké 's/he has not belched' }\end{array}$

behave like the CV verbs in (19a). We find that this is not the case; rather, they behave like the CVC verbs in (19b), which negate by affixing a -C-, a copy of the verb final consonant, and $\mathrm{a}-\mathrm{V}$, which harmonises with the root vowel. I claim that the VG sequence is not a diphthong but a vowel followed by a palatal glide. This stem-final glide surfaces in the suffix just as the -C does in other CVC verbs [Urua 1990; Akinlabi \& Urua 1993]. More importantly, treating CVG sequences as CVC stems rather than as CV stems provides a generalisation for dealing with verb suffixes in the language. Essentially the verb suffix is $-\mathrm{CV}$, but, through assimilation processes, the different verb structures realize different melodies at the surface level.

In an effort to maintain the diphthong analysis, one reviewer for this journal has suggested that through the process of suffixation, the offglide /j/ is promoted up the tree; in other words, there would be glide hardening. While possible, this 
approach simply complicates the analysis. Moreover, if the stem vowel were a diphthong, one might expect the suffix vowel, which is a copy of the preceding stem vowel, to be either a diphthong itself or a vowel comparable to the second component of the diphthong. This is not the case; the suffix vowel in the CVG cases is always the initial vowel in the stem and never the second component of the diphthong.

3.3 Ideophonic lengthening. Another function of lengthening in Ibibio is to indicate intensification. This type of lengthening is strictly ideophonic, as explained in Essien [1979]. Only CV verbs or verbs with final nasal consonants may be lengthened, as in (20). Verbs ending with oral stops cannot be lengthened. Rather, intensification in such verbs is marked by the repetition of the entire verb, as in (21).

$\begin{array}{ll}\text { dá } & \text { 'stand' } \\ \text { ń dááa ... } & \text { 'I stood for a long time.' } \\ \text { sé } & \text { 'look' } \\ \text { ń sééé ... } & \text { 'I looked for a long time.' } \\ \text { bj̀ } & \text { 'receive' } \\ \text { ń bòj̀̀ ... } & \text { 'I received many times.' } \\ \text { nám } & \text { 'perform/do' } \\ \text { ń námmḿm ... } & \text { 'I performed for a long time.' }\end{array}$

(21) dép 'buy'

ń 'dép ń 'dép ń 'dép ... 'I bought many things/times.'

bók 'cook'

ḿ 'bók ḿ 'bók ḿ 'bók ... 'I cooked many things/times.'

The fact that only vowels and nasals but not oral stops get lengthened this way is not as mysterious as it is made out to be in Essien [1979]. This can be accounted for phonetically by the nature of the segments because of the nature of their articulatory occlusion, which is [-sonorant], whereas vowels and nasals may be more readily lengthened since they are [+sonorant]. It is therefore possible that segments with the feature specification [+sonorant] may be prolonged extensively, at least as far as the articulatory organs and air stream permit, but those which are [-sonorant] cannot be so prolonged. This does not in any way suggest that an oral stop length contrast might not be attested in other languages such as Italian.

3.4 Ibibio morphophonemics. At this point, it is useful to introduce some morphophonemic material for a better understanding of the issue of length. Stop consonants are lenited in an intervocalic environment, both lexically and postlexically, creating homorganic continuants, taps, and approximants, thus, $\mathrm{p}, \mathrm{b} \rightarrow$ 
$[\beta] ; / t, d / \rightarrow[r]$, and $/ \mathrm{k} / \rightarrow[\mathrm{R}]$. Examples in (22) illustrate these changes with reflexive verbs.

(22) dip 'hide'

$$
\begin{aligned}
& \text { dịp + Refl } \rightarrow \text { / díp }+ \text { V/ } \rightarrow \text { / dípé/ } \rightarrow \text { [díßé] 'hide oneself' } \\
& 1 \text { dı́p }+\mathrm{Neg} \rightarrow / 1 \text { dı́p }+\mathrm{CV} / \rightarrow / 1 \text { dı́p }+ \text { pé/ } \rightarrow \text { [1 díppé] } \\
& \text { yàt 'wear (e.g. hat) on head' } \\
& \text { 's/he's not hiding' } \\
& \text { yàt }+\operatorname{Refl} \rightarrow / \text { yàt }+\mathrm{V} / \rightarrow \text { / yàtá/ } \rightarrow \text { [yàrá] } \\
& \text { 'wear on one's head' } \\
& 1 \text { yàt }+\mathrm{Neg} \rightarrow / 1 \text { yàt }+\mathrm{CV} / \rightarrow / 1 \text { yàt }+\mathrm{ta} / \rightarrow \text { [1 yàttá] } \\
& \text { 's/he's not wearing on } \\
& \text { the head' }
\end{aligned}
$$

$$
\begin{aligned}
& \text { fík 'cover' }
\end{aligned}
$$

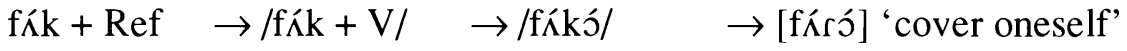

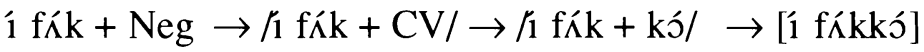

$$
\begin{aligned}
& \text { 's/he's not covering' }
\end{aligned}
$$

In (22) the reflexive marker is a $-\mathrm{V}$ suffix. When this suffix is affixed to a CVC verb, the environment for intervocalic consonant lenition is satisfied and, as expected, the final consonant becomes lenited. This applies to all oral voiceless and voiced stops in this position. However, when a $-\mathrm{CV}$ suffix is affixed to a CVC verb stem to mark negation, for instance, among other functions, consonant lenition does not take place, even though the conditions for its operation have been satisfied. This is part of what is to be accounted for in this paper. Falling out from this is the issue of suffix vowels. Only verb stems take -CV suffixes and it is important to note that verbal suffixes harmonise with the stem vowels. The correlation of the stem vowels with the suffix vowels is repeated in (23).

(23) Verb Stem Vowel

[i, i, e]

$[\mathrm{u}, \mathrm{u}, \partial, \mathrm{o}]$

$[\Lambda$, o]

[a]
Corresponding Suffix Vowel

$$
\begin{aligned}
& \text { e } \\
& \text { o } \\
& \text { o } \\
& \text { a }
\end{aligned}
$$

\subsection{Previous analyses of length}

Essien $[1979,1990]$ rightly regards length as a suprasegmental feature, which may sometimes be phonologically contrastive, sometimes predictable from morphophonemic processes, and sometimes unpredictable. Umoh [1985] supports Essien's position but takes it a step further by looking at length from an autosegmental viewpoint. Her representation of both long vowels and consonants is provided in (24)-(25). 
(24)

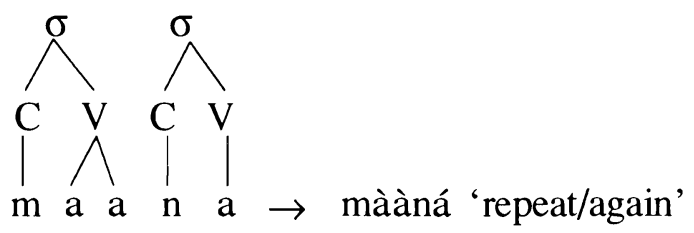

(25)

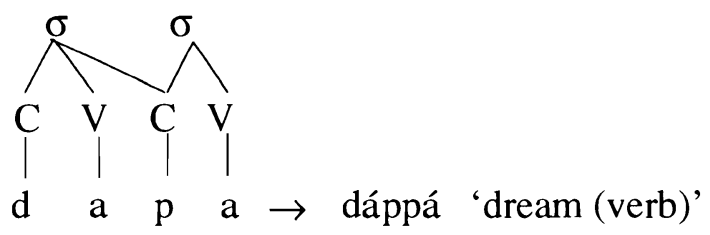

By modifying the structure in (25), we can represent a branching intervocalic consonant, as in (26). This structure has the advantage of capturing both predictable (morphological) and unpredictable consonant length in Ibibio, as well as showing that the intervocalic consonant is long.

(26)

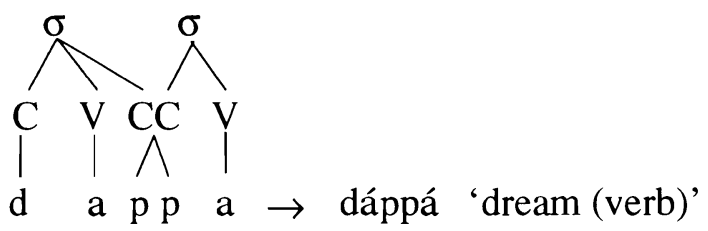

Cook [1985], in discussing the question of ambisyllabicity in Efik, proposes what he calls "Open Transition" to account for the variability of consonants at syllable boundaries. According to him, the Open Transition (OT) is a type of juncture which is important in order "to be able to specify the correct organisation of consonants and vowels into syllables and syllabemes" [1985: 65]. In other words, Open Transition determines what consonants occur in what position in a syllable in Efik. Hyman [1982], in examining length in Gokana, dispenses with the syllable altogether since, for him, the syllable does not appear to be germane to the length issue in this language. Instead, he posits different representations for length arising from morphological processes and length arising from phonological processes. However, Hyman [1990] revisits the issue of vocalic length in Gokana and modifies his earlier position about the presence of syllables in this language, showing that, in Efik, the syllable and foot are crucial in resolving the idiosyncratic behaviour of certain consonants in certain positions. This analysis is related to the situation in Ibibio, where consonants also vary depending on what position they occupy in the syllable. However, we must point out that in Ibibio, as opposed to Efik, there is sufficient evidence to distinguish between open and closed syllables, as will be shown in 5.2. Given the above and the current work on prosodic 
morphology, we now turn our attention to how length may best be accounted for in Ibibio by adopting moraic theory.

\subsection{Length and syllable weight in Ibibio}

From the data we have seen so far, it is obvious that length mainly occurs contrastively in verbs and their derivatives. Three types of processes are attested in the data on Ibibio length, viz. consonant lenition/lengthening, vowel lengthening/ truncation and compensatory lengthening. It would be difficult, from a purely segmental point of view, to account for why these processes occur in certain contexts but not in others, even when these contexts are similar, and especially when it has been shown that both consonant lengthening and lenition occur in the same CV-V phonological environment. Consequently, I adopt the moraic approach to account for length phenomena in Ibibio.

5.1 Moraic phonology. In my analysis of length here, I adopt the theory of moraic phonology, which adopts a basic assumption that languages make a weight distinction between light and heavy syllables having one and two moras, respectively. A heavy syllable may have one of the following structures: CVV, CVC, CVVC, or CVCC. This is completely language dependent.

Weight considerations are important for both phonological and morphological reasons in language; for instance, it is crucial to stress placement in stress languages. Onset consonants are not weighted since they are never assigned to any mora. A syllable weight distinction is largely dependent on whether or not such languages have a vowel length distinction [Hyman 1985, McCarthy \& Prince 1986, Hayes 1989]. Since we have shown Ibibio to have contrastive length with nasal consonants and vowels, there appears to be strong motivation for a weight distinction. Thus, the claim made here is that Ibibio makes a distinction between heavy and light syllables [Akinlabi \& Urua 1993; Akinlabi 1995]. This claim is justified within the context of moraic theory because Ibibio manifests a vowel length contrast, as we have already shown.

In addition to a moraic theory of weight, underspecification theory [Archangelli 1988] is evoked in positing the velar consonant as an underspecified consonant in Ibibio, since it is this consonant that is often used to fill an empty -C- slot in the consonant tier [Urua 1990, 1992].

5.2 An analysis of Ibibio. The data in (27) provide a sample of monosyllabic verb stems with different syllable structures. The CV stems are both monosyllabic and monomoraic in Ibibio as in other languages. The examples in (27b), though monosyllabic, are all bimoraic in Ibibio.
a. $\mathrm{CV}$
dí
'come'
b̀̀ 'receive'

b. $\mathrm{CV}(\mathrm{V}) \mathrm{C}$

$\begin{array}{llll}\text { dép 'buy' } & \text { déép 'scratch', } \\ \text { bj̀k 'cook (soup)' } & \text { bj̀jk 'nurture' } \\ \text { nám 'perform/do' } & \text { náám 'intoxicate' }\end{array}$


I treat the coda consonant in CVC structures in Ibibio as weight-bearing, so that, together with the root vowel, the syllable is bimoraic. It does not simply acquire a mora from weight by position [Hayes 1989]. However, verbs having CVVC structure are monosyllabic but bimoraic by virtue of the fact that they have long vowels, each vowel comprising two moras. The question is this: does a CVC stem have the same weighting as a CVVC stem, or is a CVVC stem monosyllabic and trimoraic? The position adopted here is that both CVC and CVVC structures are monosyllabic and bimoraic. The CVVC structure does not take a -CV suffix but rather a -V suffix. So, it has the same weight as a CVC structure and is therefore not trimoraic in itself. Once it acquires a $-\mathrm{V}$ suffix, thereby creating a CVVCV structure, it becomes disyllabic and trimoraic.

Ibibio attests few cases of long vowels contrasting with short ones in open syllables (pointed out earlier in section 3.1). Although a few cases of long vowels are attested in open syllables, e.g., kàá 'go' and nàa 'lie down', these do not contrast with short ones. Our reason for distinguishing between $\mathrm{CV}$ and CVC stems arises from the fact that $\mathrm{CV}$ stems need to lengthen the stem vowel to a CVV-structure before affixing a -CV suffix. In other words, a CV stem needs to be made heavy before -CV suffixation. This requirement is not needed for CVC stems, as illustrated in (29), as they are already considered heavy.
a. dí 'come
ń díi-Ré
b. mé 'endure'
ḿ méé-Ré
'I am not coming'
c. nò 'give'
ńn nò̀-Ré
'I am not enduring'
d. dù 'be alive'
ń dùù-Ró
'I am not giving'
'I am not alive'
a. dép 'buy'
ń dép-pé
'I am not buying'
b. sín 'put'
ń sín-né
'I am not putting'
c. kòp 'hear'
ń kòp-pó
'I am not hearing'
d. kpán 'fold'

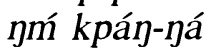
'I am not folding'

Further evidence supporting a moraic analysis is found in compensatory lengthening, where deletion of a stem final $\mathrm{C}$ in a bimoraic CVC stem necessitates lengthening of the stem vowel to fill the position of the vacated mora. This is discussed in section 5.2 .1 below.

The maximum length for an Ibibio verb root is two syllables. Hence, disyllabic verbs may be either bimoraic or trimoraic, as in (30) and (31), respectively. In (30) we have examples of disyllabic/bimoraic verbs, while those in (31) are disyllabic/ trimoraic. In (31a-d), trimoraicity is determined by the fact that there are bimoraic long vowels plus a final moraic vowel. In (31e-g), the third mora arises from the presence of the long consonants, which have weight by position, in addition to the
(30) a. fèré
'run'
b. bárá
'make (a) fire'
c. kéßé kébé
'take enema'
d. tòßó tòbó
'place (an) order' 
(31) a. fááná 'argue'

b. mééné 'delay in responding'

c. tòòró 'praise'

d. bì̀ró 'respond'

e. típpé 'bore (a) hole'

f. séppé 'make (a) mess'

g. wóńฺ 'turn around'

(32) a. tém 'cook'

tém-é 'be on fire'

tém-mé 'remove cooking from fire'

b. fáák 'wedge between two objects'

fáR-á 'be wedged between two objects'

fák-ká 'remove wedged object'

c. sày 'walk ahead'

sàn-á 'walk'

sàà-ná 'walk (Freq)

d. kj̀p 'lock'

$k \grave{\partial} \beta-\delta \quad$ 'be locked'

kjp-pó 'unlock'

kj̀̀-mó 'unlock (Freq)'

weight of the two vowel nuclei in the verb. These are all underived items. However, there are many derived verbs in Ibibio comparable in form to what is found in (30) and (31), as exemplified in (32).

Length in Ibibio may therefore be seen as operating to preserve syllabic weight oppositions. These weight oppositions include monosyllabic, monomoraic stems (i. e., CV); monosyllabic, bimoraic stems (i. e., $\mathrm{CV}(\mathrm{V}) \mathrm{C}$ ); disyllabic, bimoraic stems (i. e., CVCV); and finally disyllabic, trimoraic stems (i. e., CVVCV and CVCCV). There are no free standing verbs with four moras. Where such a possibility might arise, especially in cases where the root vowel is long in addition to a potential long consonant, the root vowel becomes truncated, leaving the weight trimoraic. Conversely, where the root vowel is short and there is a possibility of the syllable weight requirement not being met, the root vowel is lengthened to meet the weight requirements of the verb, as in (34).

Note that, in (33) and (34), the verb roots are monosyllabic/bimoraic, even though the verb stem in (33) has a long vowel. But the derived verbs are disyllabic and trimoraic. If the verb root in (33) were trimoraic, assuming the final $\mathrm{C}$ is weight-bearing, - CV suffixation would have created a potential four moras verb, as for example, *fáák-ká and *fáák-Ná. But a four mora weight is not permitted in 
(33) a. fáák 'wedge between two objects'

b. fáák + CV $\rightarrow$ fáák + ká $\rightarrow$ fák + ká $\rightarrow$ fák-ká $\rightarrow$ fákká 'remove wedged object'

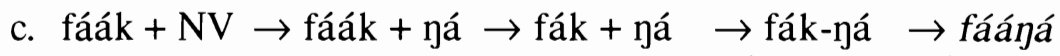

'remove wedged object (Freq)'

(34) a. kìp 'lock'

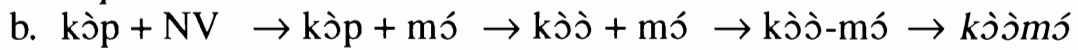

'unlock (Freq)'

Ibibio and it also appears that this is rarely attested in most languages [Hayes 1989, McCarthy \& Prince 1990]. To prevent such a situation from arising, the root vowel becomes truncated in (33b-c), leaving a bimoraic root on which suffixation applies. The long vowel in (33c) is a result of compensatory lengthening from the loss of the final root consonant. This process is discussed in more detail in 5.2.4 below. Conversely, in (34a), the vowel of the verb root is short. To derive (34b) which demands that it be disyllabic and trimoraic, the root vowel is lengthened compensatorily after the deletion of the verb final $\mathrm{C}$ to satisfy the weight requirements. Our position as argued earlier is that CVVC roots are equivalent to CVC with regard to weight.

Table 4. Verb roots, structure, and weight

$\begin{array}{lll}\text { Verb } & \text { Syllables } & \text { Weight } \\ \text { CV (dí 'come') } & \text { Monosyllabic } & \text { Monomoraic } \\ \text { CVV (kàá 'go') } & \text { Monosyllabic } & \text { Bimoraic } \\ \text { CVCV (fèré 'run') } & \text { Disyllabic } & \text { Bimoraic } \\ \text { CVVCV (bààná 'share') } & \text { Disyllabic } & \text { Trimoraic } \\ \text { CVCCV (d'ppé 'lift up') } & \text { Disyllabic } & \text { Trimoraic }\end{array}$

The weight distinction is important in Ibibio prosodic morphology because it explains why certain phonological processes may not necessarily take place in apparently identical phonological environments. Consider, for instance, the process of consonant lenition in Ibibio. As pointed out in section 3, this process occurs in intervocalic position. But, not surprisingly, long consonants are not affected by this weakening process. If weakening applied to the long consonants, then the integrity of these consonants would be lost. More crucially, it shows that consonant lenition is only permissible in light-light bimoraic (CVCV) and heavy-light trimoraic (CVVCV) feet. In this case, only the vowels make up the moras. It is therefore vital that a distinction be established between light-light (CVCV) and heavy-light feet (CVVCV/CVCCV), as well as between heavy-light (CVVCV and CVCCV), to account for why these processes may not occur in similar phonological environments [Shaw 1992; Akinlabi \& Urua 1993; Akinlabi 1995]. Further evidence to show that these processes are based on syllable weight distinctions is provided in (35). 

a. sàná 'walk
í sàyá-ké
's/he is not walking'
b. fèré 'run'
1 fèré-ké
' $\mathrm{s} /$ he is not running'
c. fááná 'argue'
1 fááná-ké
' $\mathrm{s} /$ he is not arguing'
d. tò̀̀ò 'praise'
i tòòró-ké
' $\mathrm{s} /$ he is not praising'
e. dippé 'lift up'
1 dippé-ké
f. séppé
'make (a) mess'
i séppé-ké
's/he is not lifting up'
' $\mathrm{s} / \mathrm{he}$ is not making (a) mess'

In (35) the negative marker is -ké. Crucially, observe that lenition of $/ \mathrm{k} /$ fails to take place even though an intervocalic environment has been satisfied. This is simply because the syllables in (35) already meet the criteria for light-light or heavy-light feet. /-ké/ in itself is only a light CV syllable and does not constitute a proper foot, i. e., light-light or heavy-light. However, it may be seen as extraprosodic. The first two syllables already constitute a foot; therefore, lenition cannot take place outside of a complete foot, as in (36). Given our earlier submission, consonant lenition and lengthening may occur only in a light-light or heavy-light feet, respectively. When such weight distinctions are met, these processes can occur. However, when these weight distinctions are not met, it is impossible for these same processes to take place. In (36), further evidence is provided to show that consonant lenition and lengthening can only take place within specified syllable structures constituting different foot structures.

(36) a. CV

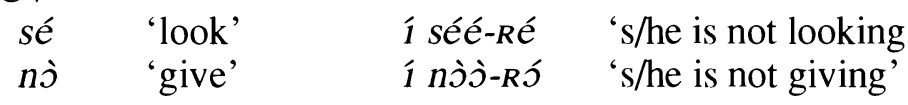

b. CVC
dép
'buy'
1 dép-pé
's/he is not buying'
màn 'give birth'
í màn-ná
' $\mathrm{s} / \mathrm{he}$ is not giving birth'
wùùt
'pull down'
1 wùù-ró
' $\mathrm{s} / \mathrm{he}$ is not pulling down'
sj̀̀k 'erase'
i ş̀̀̀-Ró
' $\mathrm{s} /$ he is not erasing'

c. CVVC

In (36), the same negative marker /-ké/, encountered in (35), is realised phonetically as $[-\mathrm{RV}]$ when it occurs with $\mathrm{CV}$ verbs, and as $-\mathrm{CV}$ with $\mathrm{CV}(\mathrm{V}) \mathrm{C}$ verbs. However, notice that consonant lenition and lengthening have taken place in these examples even though the verb roots are monosyllabic/monomoraic or monosyllabic/bimoraic. The addition of /-ké/, a -CV suffix, creates a heavy-light (either CVVCV or CVCCV) foot, which enables these two processes to take place. In (36b-c) where the verb root is already bimoraic, there is no need to lengthen the root vowel, as was necessary for the examples in (33a and c), to obtain a heavylight CVV-CV. The assimilatory process in (33) is accounted for through underspecification theory [Archangelli 1988].

It has been argued that $/ \mathrm{k} /$ is the underspecified consonant in Ibibio [Urua 1990, 1992] for the following reasons. In many morphophonemic instances, it serves as the "back-up" consonant where a consonant is required to fill the position of an 
empty -C- slot. If we look at the data in (36), we see that monosyllabic verbs without a coda are negated by an $-\mathrm{R} V$ suffix where the $-\mathrm{V}$ - harmonises with the root vowel. Recall also that the voiceless stops $[\mathrm{p}, \mathrm{t}, \mathrm{k}]$ are lenited in intervocalic position, resulting in $[\beta, r, \mathrm{R}]$. Notice that the $-\mathrm{C}$ - of the $-\mathrm{CV}$ suffix on the $\mathrm{CV}$ verbs is always an $-\mathrm{R}-$, the same consonant that is realised after the lenition of $/ \mathrm{k} /$ in (36c). The argument here is that, since the suffix consonant may be assimilated as in (36b), a consonant that satisfies this function is / $\mathrm{k}$ / [Essien 1990; Urua 1990, 1992; Akinalbi \& Urua 1993]. Where there is no coda consonant, as in (36a), the consonant of the -CV suffix, which is $/ \mathrm{k} /$ underlyingly, assimilates to the coda consonant; but where the coda consonant is $/ \mathrm{k} /$ on the surface, this application is vacuous. Further evidence supporting $/ \mathrm{k} /$ as the default consonant is presented in the next section on compensatory lengthening.

5.2.1 Compensatory lengthening. There is reason to believe that the base of prosodic morphology in Ibibio is a monosyllabic structure, i. e., CV(C) [Essien 1978, 1979, 1990; Urua 1990]. Most morphophonemic processes hinge on the $\mathrm{CV}(\mathrm{C})$ verb root. I present here evidence from compensatory lengthening to show this to be the case. Chene \& Anderson [1979] and Hayes [1989], among others, discuss the phenomenon of compensatory lengthening, Hayes [1989: 260] defining it as "the lengthening of a segment triggered by the deletion or shortening of a nearby segment". Given this definition, compensatory lengthening in Ibibio is triggered mainly by the absence of coda consonant segments or by the deletion of coda consonant segments in order to satisfy syllable weight requirements. Let us consider the data in (37), which we have already encountered in section 3.

As pointed out in 3.2, there are several other ways of marking frequency in Ibibio, some of which include lengthening, suffixation, and degemination. However, for our purposes, in (37)-(40) we will concentrate on compensatory lengthening as a marker of frequency. To obtain a frequentative form such as that in (37a) in which the verb root has a CVC structure and is bimoraic, we assume a -CV suffix whose -C-is underlyingly specified [Nasal]. The suffix vowel, as usual, harmonises with the root vowel. The coda consonant is deleted, thereby creating an empty moraic slot which is filled by the lengthening of the root vowel. Where the verb is disyllabic, i. e., either CVCV or CVCCV as in (37c-d) and (39)-(40), such verbs are treated as if they only had a CVC structure. It is as if the final $-\mathrm{V}$ - and $-\mathrm{CV}$ portions are "extra-prosodic", with the result that the same process that applied to the CVC forms is also applicable to the CVCV and CVCCV forms, discountenancing the last $-\mathrm{CV}$. Observe that the forms with coronals as the coda consonant in (38b), (39), and $(40 \mathrm{c})$ do not have the expected alveolar nasal as the suffix consonant. There appears to be a constraint against coronals appearing as suffix consonants when the suffix is specified as [Nasal] [cf. Paradis \& Prunet 1989]. This consonant is realised in such cases, once again establishing the status of the velar consonant as the default consonant in Ibibio.

Further evidence for this position is found in verbs without codas, as in (37). Notice that again the suffix consonant is the velar consonant. Two things take place with respect to verbs having a CV structure. One is that, although there is no 
coda consonant to be deleted, the root vowel is still lengthened to create a CVV$\mathrm{CV}$ structure, as in (37a-b). In the event that the root vowel is not lengthened to fill the slot of a deleted consonant, a velar consonant is introduced as the coda as in the frequentative forms in (37), where the output is CVngV or CVkkV.

(37) $\mathrm{CV}$
a. nว̀
'give'
nòn-ク́s 'give (Freq)'
nj̀̀̀-ñó 'feed someone (e.g., a child)'
b. kpì 'cut (with a machete)'
kṕ́k-ké 'cut right through'
kpéé-né 'cut right through (Freq)'

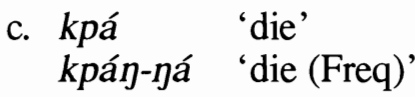

(38) CVC
a. dép
'buy'
déé-mé 'buy (Freq)'
b. yàt 'wear (e.g., hat) on the head'
yààrá 'remove (e.g., hat) from head (Reversive)'
yàà-’á 'remove (e.g., hat) from head (Frequentative)'

(39) CVCV

$\begin{array}{ll}\text { fèré } & \text { 'run' } \\ \text { fèè-yé } & \text { 'run (Freq)' }\end{array}$

(40) CVCCV
a. díppé 'lift up'
díi-mé 'lift up (Freq)'
$\begin{array}{ll}\text { b. fákká 'remove wedged object' } \\ \text { fáá-ná } & \text { 'remove wedged objects (Freq)' }\end{array}$

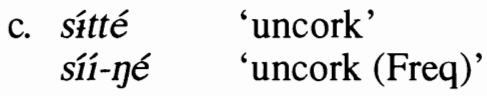

These processes take place in order to satisfy the weight requirement, which is heavy-light, in order for compensatory lengthening to take place. The suffix nasal consonant is, of course, identical to the coda nasal, thereby creating a long nasal consonant that acquires a mora from the coda through weight by position, deriving a trimoraic disyllable after suffixation. These satisfy the syllabic weight 
requirements for this process. Secondly, the default nasal consonant is realised, even though there is none at the coda for the suffix consonant to copy. It has been shown that adopting moraic theory provides a straightforward and easy explanation for compensatory lengthening in Ibibio, since the deletion of the coda $\mathrm{C}$ in a CVC structure (which has a weight unit of a mora) and the subsequent lengthening of the root vowel to occupy the position of the deleted coda consonant, occurs just to maintain the weight of the syllable that is bimoraic.

Other processes to be examined in support of the syllabic weight theory in Ibibio include the reciprocal and reflexive formations, as illustrated in (41) and (42). Reciprocal action is action performed by two or more persons for each other. This is grammatically expressed in Ibibio through prefixation and suffixation. Reversive action, on the other hand, indicates that the action expressed by a verb is reversed, not necessarily negated, since both positive action and a reversed action may be negated, as already explained in 3.2.2.

(41) Reciprocation

a. CV
má
'love/like'
è-dú-mà-kà
'love one another'
sé
'look'
è-dú-sè̀̀-rè
'look at one another'

b. CVC

$\begin{array}{ll}\text { kít } & \text { 'see' } \\ \text { kòp } & \text { 'hear' } \\ \text { kóm } & \text { 'greet' } \\ \text { tán } & \text { 'talk' }\end{array}$

è-dú-kìt-tè 'see one another'

è-dú-kòp-pò 'listen to one another'

è-dú-kj̀m-mj̀ 'greet one another'

è-dú-tàn-クà

'exchange strong words with one another'

c. CVCCV

képpé 'wink at'

kpj̀kkó 'hit'

è-dú-kèppè 'wink at one another'
è-dú-kpj̀kkj̀ 'hit one another'

It is clear that the reciprocal suffix is $-\mathrm{CV}$ where the verb root is $\mathrm{CV}(\mathrm{C})$. But where the verb is disyllabic, CVCV/CVCCV, there is no reason to add an additional $-\mathrm{CV}$ suffix. The basic structure of the verb is maintained. The - $\mathrm{CV}$ suffix is only necessary to balance the weight requirements of a monomoraic syllable, making it bimoraic or maximally trimoraic, as the case may be.

Reflexivisation in Ibibio is marked by a -V suffix which has the effect of weakening a preceding final stop, be it oral or nasal. Connell [1991] suggests that weakening occurs even for nasal stops in Ibibio in similar environments. Word final oral stops become corresponding continuants or taps depending on the place features of the stop. For instance, as already indicated in section 3.4 above, $p, b \rightarrow$ $[\beta], t, d \rightarrow[r]$ and $/ k / \rightarrow[R]$. Observe that when the $-V$ suffix is affixed to a CVC verb root, the final consonant becomes weakened, but when a -CV suffix is added to the same CVC verbs, no weakening occurs; rather, there is consonant replication. All of these serve to show that syllable weight is crucial to Ibibio phonology. 
(42) Reflexivisation
a. sín
síné
í-sínné
'put'
'put on oneself'
's/he is not putting on'
dípé $\rightarrow$ dỉßé
i-díppé
b. dip
'hide'
'hide oneself'
's/he is not hiding'
c. yàt
yàtá $\rightarrow$ yàrá
í-yàttá
'wear (on the head)'
'wear on one's head'
' $\mathrm{s} /$ he is not wearing (on the head)'

The position taken in this paper is not at variance with the argument concerning the relevance of foot structures in Ibibio [Akinlabi 1995] and in Efik [Hyman 1990]. Ultimately, syllable structure is intricately linked to foot structure. If we consider the examples in (41), it will be observed that even though the structure mà-kà meets the requirement for the weakening of the voiceless velar stop, this does not occur, possibly because the -kà does not constitute part of a foot with mà. Alternatively, the failure of $-k$ to lenite in this example might be historical. 3

\subsection{Conclusion}

In this paper I have provided a descriptive account of length in Ibibio and shown that, using a moraic account, length can easily be accounted for as occurring to satisfy the syllabic weight oppositions in the language. It explains, for instance, why certain phonological processes such as consonant lengthening and lenition, vowel lengthening and truncation, may occur in one instance but fail to occur in another, even when the phonological requirements are satisfied. However, if a distinction is made between light-light and heavy-light feet, then it is easy enough to offer a satisfactory account [Akinlabi \& Urua 1993; Akinlabi 1995]. Different syllable weight requirements are therefore needed for the different verbal suffixes to yield the surface output. Using underspecification theory, the fact that velar consonants emerge in the output, either as stops, continuants or nasals, where they were not present overtly as part of the surface structure, is accounted for if the velar consonant is regarded as the default consonant in Ibibio.

${ }^{3}$ This position has been suggested by an anonymous reviewer. 


\section{REFERENCES}

Akinlabi, Akinbiyi. 1995. "Prosodic truncation and template satisfaction in Ibibio verbs." In K. Owolabi (ed.), Language in Nigeria: Essays in honour of Ayo Bamgbose. Ibadan: Group Publishers. Pp. 75-90.

Akinlabi, Akinbiyi M. and Eno E. Urua. 1993. "Prosodic target and vocalic specification in Ibibio verbs." Proceedings of the Eleventh West Coast Conference on Formal Linguistics. Pp. 1-14.

Archangelli, Diana. 1988. "Aspects of the theory of underspecification." Phonology 5:183-208.

Barkai, M. 1974. "On duration and spirantization in Biblical Hebrew." Linguistic Inquiry 3: 456-459.

Boys, William E. 1978. "Ibibio phonology," Ph.D. dissertation, The Ohio State University.

Chene, E. B. de and Stephen R. Anderson. 1979. "Compensatory lengthening." Language 55, 3: 505-535.

Clements, George N. and Samuel Jay Keyser. 1983. CV Phonology: A generative theory of the syllable. Cambridge, Massachusetts: MIT Press.

Connell, Bruce. 1987. "Temporal aspects of labiovelar stops." Work in Progress 20: 53-60. Department of Linguistics, University of Edinburgh, Edinburgh.

Connell, Bruce. 1991. "Phonetic aspects of Lower Cross languages and their implications for sound change." Ph.D. dissertation, University of Edinburgh.

Cook, Tom L. 1969. “The Efik consonant system." Seminar Paper presented to the Department of Linguistics and Nigerian Languages, University of Ibadan.

Cook, Tom L. 1985. "An integrated phonology of Efik." Ph.D. dissertation, University of Leiden, Leiden, The Netherlands.

Crystal, David 1991. A Dictionary of Linguistics and Phonetics. ( $3^{\text {rd }}$ edition) Oxford: Blackwell.

Essien, Okon E. 1978. "Possessive pronominalization and the so-called picture nouns in Efik." Studies in African Linguistics 9, 2: 121-142.

Essien, Okon E. 1979. "Length and nasalisation in Ibibio." Work in Progress 12:109-121. Department of Linguistics, University of Edinburgh, Edinburgh. 
Essien, Okon E. (ed.) 1983. The Orthography of the Ibibio Language. Calabar: Paico Press.

Essien, Okon E. 1990. A Grammar of the Ibibio Language, Ibadan, Nigeria: University Press Limited.

Faraclas, Nicholas G. 1989. "Cross River." In John Bendor-Samuel (ed.), The Niger-Congo Languages. Lanham, Maryland: University Press of America. Pp. 377-399.

Guerssel, Mohand 1977. "Constraints on phonological rules." Linguistic Analysis 3, 3: 267-305.

Hayes, Bruce 1989. "Compensatory lengthening in moraic phonology." Linguistic Inquiry 20, 2: 253-306.

Hyman, Larry M. 1982. "The representation of length in Gokana." In Proceedings of the First Annual West Coast Conference on Formal Linguistics. Pp. 198-206.

Hyman, Larry M. 1985. A Theory of Syllable Weight. Dordrecht, Holland: Foris Publications.

Hyman, Larry M. 1990. "Non-exhaustive syllabification: evidence from Nigeria and Cameroon." In M. Ziolkowski, M. Noske, and K. Deaton (eds.), Parasession on the Syllable in Phonetics and Phonology. Chicago: Chicago Linguistic Society. Pp. 175-195.

Kaufman, Elaine M. 1968. "Ibibio grammar.” Ph.D. dissertation. University of California, Berkeley.

Leben, William R. 1980. "A metrical analysis of length." Linguistic Inquiry 11: 497-509.

McCarthy, John J. 1981. "A prosodic theory of nonconcatenative morphology." Linguistic Inquiry 12: 313-418.

McCarthy, John J. and Alan Prince. 1986. "Prosodic morphology." MS. University of Massachusetts, Amherst and Brandeis University.

McCarthy, John J. and Alan Prince. 1990. "Foot and word in prosodic morphology: the Arabic broken plural." Natural Language and Linguistic Theory 8, 209-284.

Paradis, Carole and Jean-François Prunet. 1989. "On coronal transparency." Phonology 6: 317-348. 
Poser, William J. 1990. "Evidence for foot structure in Japanese." Language 66, 1: 78-105.

Schein, Barry and Donca Steriade. 1986. "On geminates." Linguistic Inquiry 17: 691-744.

Shaw, Patricia A. 1992. "Templatic evidence for the syllabic nucleus." North East Linguistic Society Proceedings 23: 463-477. Amherst: GLSA.

Umoh, Francisca. 1985. "Aspects of Ibibio phonology: An autosegmental approach.” M.A. thesis, Ibadan, Nigeria.

Urua, Eno E. 1987. "Segment deletion and aspects of tone in Ibibio." M.A. thesis, Ibadan, Nigeria.

Urua, Eno E. 1990. "Aspects of Ibibio phonology and morphology." Ph.D. dissertation, Ibadan, Nigeria.

Urua, Eno E. 1992. "Underspecification and the morphophonemics of Ibibio /k/." Journal of Humanities : 9-18. Uyo, Nigeria.

Utip, Eno M. 1991. "A comparative study of Efik, Ibibio and Annang vowels." M.A. thesis, University of Port Harcourt, Nigeria.

Van der Hulst, Harry and Norval Smith. 1982. "An overview of autosegmental and metrical phonology." In H. van der Hulst and N. Smith (eds.), The Structure of Phonological Representation (Part 1). Dordrecht, Holland: Foris Publications. Pp. 1-46.

Welmers, William E. 1973. African Language Structures. Berkeley: University of California Press.

Department of Linguistics and Nigerian Languages

University of Uyo

P.M.B. 1017

Uyo, Akwa Ibom State

Nigeria

enourua@skannet.com.ng
[Received April 1996; revision received April 1998; provisional acceptance July 1998; revision received August 1999; accepted October 1999] 